\title{
KONTRIBUSI KEARIFAN LOKAL DAN ETIKA BUDDHA DALAM PERSPEKTIF KEPEMIMPINAN MODERN
}

\author{
Oleh: Mulyana ${ }^{1}$ \\ Mulyanawahyu45@gmail.com
}

\begin{abstract}
Abstrak
Culture of Java have various local wisdom, one of them related to leadership such as Serat Wulang Reh and Asta Brata Teaching. Beside that, Buddha's Teaching in text Jataka also concern on leadership, called Dasa Raja Dhamma. This article aim to study the contribution of local wisdom, specially Serat Wulang Reh and Asta Brata Teaching and Buddhist Ethics, specially Dasa Raja Dhamma on leadership pattern in modern era. This research use the qualitative approach and library research method.
\end{abstract}

Key word: local wisdom, Buddhist Ethics, leadership

\section{PENDAHULUAN}

Sepanjang sejarah kehidupan manusia, masalah kepemimpinan merupakan topik yang sangat menarik untuk dibahas. Dalam ilmu sosiologi, kepemimpinan merupakan hal yang sangat penting dalam kehidupan masyarakat, dimana pemimpin selalu ada dalam berbagai kelompok. Keberadaan pemimpin sangat dibutuhkan, baik dalam lingkup kecil maupun luas. Dalam lingkup luas, rakyat suatu negara selalu mendambakan pemimpin dengan sifat kepemimpinan yang baik sehingga pemimpin mampu mengatur negara dengan baik pula.

Sejak era reformasi tahun 1998, yang ditandai dengan runtuhnya rezim Orde Baru sampai sekarang, Indonesia berada dalam krisis kepemimpinan, mulai dari level paling atas yaitu presiden sampai ke gubernur, bupati, camat, lurah bahkan sampai kepada kepala desa. ${ }^{2}$ Dalam siklus lima tahunan, bangsa Indonesia mengadakan pemilihan umum untuk memilih wakil mereka yang akan menduduki kursi DPR maupun untuk memilih persiden yang akan memimpin mereka selama lima tahun ke depan. Dalam kampanyenya, mereka memberikan janji-janji politik yang pada kenyataannya jarang direalisasikan, seolah-olah mereka tidak pernah memberikan janji tersebut sehingga mereka

${ }_{1}$ Dosen Tetep Jurusan Dhamaduta STAB Negeri Sriwijaya Tangerang Banten.

${ }^{2}$ Sulistiyo Seti Utami. 2013. Gaya Kepemimpinan Gubernur DKI Jakarta Berdasarkan Prinsip Tata Kelola Kepemerintahan yang baik (GCG). Jurnal Liquidity Vol. 2, No. 2, hal. 160. 
kehilangan kepercayaan dari rakyat. Untuk mengembalikan kepercayaan rakyat diperlukan pemimpin yang jujur, sederhana, dan mempunyai keberanian mengambil atau membuat suatu kebijakan dan melaksanakan kebijakan tersebut dengan baik dan konsisten.

Kearifan lokal memiliki potensi yang besar sebagai sumber acuan dalam menentukan arah perkembangan kepemimpinan dalam suatu masyarakat. Pola kepemimpinan dapat mengakomodasi atau menyerap nilai-nilai kearifan lokal yang sudah berkembang terlebih dahulu dalam suatu masyarakat. Kearifan lokal merupakan produk budaya masa lalu yang patut secara terus menerus dijadikan pegangan hidup dan meskipun bernilai lokal tetapi nilai yang terkandung di dalamnya dianggap sangat universal. ${ }^{3}$ Nilai-nilai kearifan lokal telah teruji kemampuannya dalam menghadapi dan menyesuaikan diri terhadap setiap perubahan dan perkembangan zaman sehingga tetap bertahan sampai sekarang. Selain itu, nilai-nilai yang terkandung dalam agama juga dapat digunakan sebagai acuan oleh para pemimpin dalam melaksanakan tugas dan kewajibannya. Agama sebagai landasan etika dan moral bagi penganutnya memberikan kontribusi yang sangat besar terhadap pola kepemimpinan dalam suatu negara.

Kebudayaan Indonesia yang bersifat plural dan heterogen dapat melahirkan kearifan lokal (local wisdom) yang dapat memperkuat dan memperkokoh khasanah budaya bangsa Indonesia. ${ }^{4}$ Masyarakat Jawa sebagai bagian dari masyarakat Indonesia memiliki nilai-nilai yang penuh dengan nilai etika dan estetika. Masyarakat Jawa secara turun temurun telah merumuskan berbagai karakter positif, yang salah satunya berkaitan dengan kepemimpinan seperti Serat Wulangreh dan Ajaran Asta Brata. Serat Wulang Reh adalah karya sastra berupa tembang macapat karya Pakubuwana IV, Raja Surakarta. Sedangkan Ajaran kepemimpinan Asta Brata merupakan salah satu konsep yang cukup luas diapresiasi dan berasal dari naskah kuno Mahabarata. Konsep Asta Brata memberikan gambaran bagaimana seorang pemimpin atau raja dapat berperilaku sesuai dengan delapan sifat luhur dewa.

\footnotetext{
${ }^{3}$ Sartini. 2004. Menggali Kearifan Lokal Nusantara Sebuah Kajian Filsafati. Jurnal Filsafat, Jilid 37, No. 2, hal. 112.

${ }^{4}$ Nanik Herawati. 2012. Kearifan Lokal Bagian Budaya Jawa. Jurnal Magistra, No. 78, Tahun XXIV, hal 65.
} 
Buddhisme adalah suatu pedoman hidup/cara pandang terhadap kehidupan, di mana hal terpenting yang terkandung di dalamnya menurut filosofi mulia Buddha adalah memraktekkan dan mengikuti Jalan Tengah yang akan membawa kepada pembebasan tertinggi-Nibana. Untuk mencapai pembebasan tertinggi mensyaratkan bahwa sisi kesejahteraan sosial, ekonomi, politik, dan pola pemerintahan yang baik harus terpenuhi. Pemerintahan yang adil, jujur, dan bersih menjadikan rakyat sejahtera dan bahagia. Hal ini akan tercapai apabila pemimpin memiliki perilaku yang terpuji. Ajaran Buddha, dalam Teks Jataka memberikan petunjuk berkaitan dengan sepuluh karakteristik pemimpin yang baik, yang dikenal dengan Dasa Raja Dhamma.

Tulisan ini bertujuan untuk membahas kontribusi nilai-nilai kearifan lokal, seperti Serat Wulang Reh dan Ajaran Asta Brata dan nilai-nilai ajaran Agama, terutama konsep Dasa Raja Dhamma dalam implementasi pola kepemimpinan modern. Dengan dukungan nilai-nilai kearifan lokal dalam suatu masyarakat dan nilai-nilai moralitas yang terkandung dalam ajaran agama diharapkan akan menghasilkan pola kepemimpinan yang sesuai dengan sikap, keperibadian, dan harapan bagi masyarakat yang dipimpin.

\section{METODOLOGI PENELITIAN}

Penelitian ini menggunakan pendekatan kualitatif. Metode yang digunakan adalah metode kepustakaan, yaitu suatu metode yang mengandalkan informasi-informasi dari kepustakaan. Semua data yang dikumpulkan merupakan data sekunder yang diperoleh dari bahan bacaan.

\section{HASIL PENELITIAN DAN PEMBAHASAN}

\section{Kearifan Lokal Jawa tentang Kepemimpinan}

Istilah kearifan lokal adalah terjemahan dari "local genius", yang pertama kali diperkenalkan oleh Quaritch Wales pada tahun 1948-1949 dengan arti "kemampuan kebudayaan setempat dalam menghadapi pengaruh kebudayaan asing pada waktu kebudayaan itu berhubungan. ${ }^{5}$ Kearifan lokal dalam bahasa asing sering dikonsepsikan sebagai kebijakan

5 Ajib Rosidi. 2011. Kearifan Lokal dalam Perspektif Budaya Sunda. Bandung: Kiblat Buku Utama, hal. 29. 
setempat (local wisdom), pengetahuan setempat (local knowledge) atau kecerdasan setempat (local genius). ${ }^{6}$ Dengan demikian, kearifan lokal (local wisdom) dapat dimaknai sebagai gagasan-gagasan, nilai-nilai, pandanganpandangan setempat yang bersifat kebijaksanaan, penuh kearifan, bernilai baik, yang tertanam dan diikuti oleh anggota masyarakatnya tertentu yang digunakan untuk berinteraksi dengan budaya asing. Di mana lingkup kearifan lokal dapat dikelompokkan menjadi delapan, yaitu: a. normanorma lokal yang dikembangkan, seperti "laku Jawa", pantangan dan kewajiban; b. ritual dan tradisi masyarakat serta makna yang terkandung; c. lagu-lagu rakyat, legenda, mitos dan cerita rakyat yang biasanya mengandung pelajaran atau pesan-pesan tertentu yang hanya dikenali oleh komunitas lokal; d. informasi data dan pengetahuan yang terhimpun pada diri sesepuh masyarakat, tgetua adat, pemimpin sepiritual; e. manuskrip atau kitab-kitab suci yang diyakini kebenarannya oleh masyarakat; f. caracara komunitas lokal dalam memenuhi kehidupan sehari-hari; g. alat-bahan yang diperguanakan untuk kebutuhan tertentu; dan h. kondisi sumber daya alam yang biasa dimanfaatkan dalam penghidupan sehari-hari.7

Kearifan lokal Jawa merupakan bagian dari budaya yang telah hidup dan berkembang sepanjang kehidupan masyarakat Jawa dalam interaksinya dengan lingkungan, agama, dan budaya asing sehingga bersifat dinamis. Dengan adanya kontak budaya lokal dengan budaya asing akan menghasilkan difusi, asimilasi, dan akulturasi yang menyebabkan budaya di masyarakat khususnya kearifan lokal akan berubah secara cukup signifikan. Salah satu contoh kearifan lokal masyarakat Jawa yang dihasilkan dari interaksi dengan budaya asing (agama), seperti Ajaran Asta Brata dan Serat Wulang Reh Karya Raja Pakubuwana IV, yang keduanya telah mendarah daging dan diyakini oleh masyarakat Jawa sebagai pedoman dalam menjalankan kehidupan bermasyarakat. Ajaran Asta Brata dan Serat Wulang

${ }^{6}$ Wagiran. 2012. Pengembangan Karakter Berbasis Kearifan Lokal Hamemayu Hayuning Bawana. Jurnal Pendidikan Karakter, Tahun II, No. 3, hal. 330.

7 Wagiran. 2012. Pengembangan Karakter Berbasis Kearifan Lokal Hamemayu Hayuning Bawana. Jurnal Pendidikan Karakter, Tahun II, No. 3, hal. 330. 
Reh memberikan tuntunan kepada masyarakat berkaitan dengan sifat-sifat pemimpin yang baik.

Makna dari Serat Wulang Reh secara etimologi adalah serat (surat), wulang/piwulang (ajaran/pelajaran), dan reh (memerintah, memimpin), yang dalam arti bebasnya adalah surat yang berisi pelajaran, piwulang untuk memimpin. Serat Wulang Reh terdiri dari 13 tembang, tetapi yang berkaitan dengan piwulang kepemimpinan, terutama sifat-sifat pemimpin sejati, ada lima tembang. Kelima tembang yang mengandung piwulang kepemimpinan tersebut adalah: a. Tembang Dhandhanggula, berisi ajaran kepemimpinan yang mengungkap sifat-sifat pemimpin seperti: 1) ikuti ajaran hati; 2) jangan menipu diri sendiri; 3) sabar dan teliti; 4) belajar berkembang untuk kesempurnaan; 5) berguru dan bacalah alam semesta; dan 6) pahami tentang perbedaan. b. Tembang Kinanti, yang berisi ajaran kepemimpinan, seperti: 1) bisa merasakan penderitaan orang lain; 2) pengendalian diri; 3) rendah hati; 4) ciptakan lingkungan yang bersih; 5) ciptakan lingkungan yang bersih; dan 6) belajar dari sejarah masa lalu. c. Tembang Gambuh, yang berisi ajaran kepemimpinan, seperti: 1) pahami hokum aksi reaksi; 2) tegakkan kebenaran; 3) jangan membeda-bedakan; 4) hindari tiga kesombongan, yaitu sombong kedudukan, sombong kepandaian, dan sombong keberanian. d. Tembang Pangkur, yang berisi sifat pemimpin sejati, yang berupa: Empat Langkah Kepemimpinan, yaitu: 1) introspeksi diri; 2) dahulukan yang utama; 3) susun rencana/misi; 4) hati-hati; dan Enam Sifat Pemimpin Sejati, yaitu: 1) berpendirian teguh; 2) tidak mudah tergiur sesuatu; 3) dapat dipercaya; 4) mempunyai pengendalian diri yang kuat; 5) mempunyai visi; dan 6) ikhlas. e. Tembang Durma, yang berisi ajaran kepemimpinan yang mengungkap sifat pemimpin sejati, yaitu: 1) semua berawal dari diri sendiri; 2) jangan hanya menilai tetapi berikan solusi; dan 3) berpikir yang baik. ${ }^{8}$

Sedangkan Hasta Brata, "hasta" berarti delapan dan "bratha" berarti petunjuk, sehingga asta brata dapat diartikan delapan petunjuk, yang disimboliskan dengan sifat delapan Dewa. Makna Asta Brata menurut Adityo Jatmiko dalam Siti Supeni dan Kundharu Saddhono, it is the

${ }^{8}$ Adi Sujanto. 2013. Konsep Ideal Kepemimpinan Nusantara Pada Pemilu 2014. Majalah TANNAS, Edisi 95, hal. 33 . 
leadership concept using the symbols of the nature, namely: (1) Sun (surya), the source of energy and the source of life, (2) Moon (candra) having beautiful shine to light, (3) Star (kartika) as the guide of the direction, (4) Cloud (Mendhung), the symbol of wise, that changing into freshing rain, (5) Wind (maruta) flowing to lower place, (6) Sea, broad knowlede, having flate surface as the symbol of fair, (7) Fire (dahana), acting fairly and strict, (8) Earth, generous. ${ }^{9}$ Pola kepemimpinan dalam ajaran Asta brata adalah seorang pemimpin harus memiliki delapan sifat dewa, yaitu Dewa Indra, Yama, Surya, Candra, Anila, Kwera, Baruna, dan Agni. Kitab Manawa Dharmasastra juga memuat tentang Asta Brata yang dipetik dari nama-nama Dewa di Bhuwana Agung dan disesuaikan dengan sifat dari kepemimpinan seorang raja. ${ }^{10}$ Menurut Cokorda Rai Sudharta, Dewa Indra, Yama, Surya, andra, Anila, Kuwera, Baruna, dan Agni adalah delapan Brata yang bernama Asta Bratha yang seharusnya dihayati oleh seorang pemimpin agar meresap dalam jiwa raganya. ${ }^{11}$ Rincian delapan sifat Dewa (Astha Bratha) tersebut adalah: a. Indra Bratha, para pemimpin hendaknya mengikuti sifat Dewa Indra, yaitu sebagai dewa hujan atau dewa kesuburan/kemakmuran; b. Yama Bratha, pemimpin hendaknya mengikuti sifat-sifat Dewa Yama, yaitu menciptakan hukum, menegakkan hukum dan memberikan hukuman secara adil dan merata kepada seluruh rakyat yang bersalah; c. Surya Bratha, pemimpin hendaknya memberikan penerangan secara adil dan merata kepada semua rakyatnya dan selalu berhati-hati dalam berbuat; d. Candra Bratha, pemimpin hendaknya selalu dapat memperlihatkan wajah terang dan berseri-seri sehingga rakyat yakin akan kebenaran jiwa pemimpinnya; e. Bayu Bratha, selalu mengetahui dan menyelidiki keadaan dan kehendak yang sebenarnya terutama sekali kehendak rakyat yang hidupnya paling menderita. Sifat ini digambarkan sebagai Sang Hyang Bayu, yaitu Dewa Angin yang selalu berhembus dari tekanan tinggi ke tekanan rendah; f. Danadha Baratha, pemimpin harus bijaksana dalam menggunakan dana dan uang, jangan menjadi pemboros

${ }^{9}$ Siti Supeni dan Kundharu Saddhono. 2013. Cognitive Behavior Has Replaced The Javanese Traditional Values In Global Era. Asian Journal of Management Sciences and Education, Vol. 2, No. 2, hal. 158.

${ }^{10}$ I Made Wirata. 2011. Kepemimpinan Universal pada Era Globalisasi dalam Konsep Hindu. Jurnal Ganes Swara, Vol. 5, No. 1, hal. 98.

${ }^{11}$ I Made Wirata. Op. cit. hal. 98. 
yang dapat merugikan Negara dan rakyat; g. Baruna Bratha, pemimpin hendaknya dapat membersihkan segala bentuk penyakit masyarakat, seperti pengangguran, kenakalan remaja, pencurian, dan pengacauan politik; dan $\mathrm{h}$. Agni Bratha, pemimpin harus memiliki sifat kesatria yang disertai dengan semangat tinggi bagaikan api yang tidak akan berhenti membakar sebelum yang dibakar habis atau musnah sama sekali.

\section{Etika Buddha tentang Kepemimpinan}

Menurut P. Singer, aspek utama dari etika adalah "kehidupan yang baik", hidup layak atau kehidupan yang cukup memuaskan, yang dipegang oleh banyak filsuf dan menjadi lebih penting daripada perilaku moral tradisional. ${ }^{12}$ Etika dan petunjuk moral dalam agama Buddha didasarkan pada kitab suci Tri Pitaka, yang memuat ajaran Buddha Gautama. Etika dan petunjuk moral memberikan pedoman berperilaku dalam kehidupan seharihari dalam rangka mencapai pembebasan tertinggi (nibbana). Buddhist ethics begins with the desire to end suffering, and Buddhist concepts of right and wrong follow.13 Dalam kehidupan bermasyarakat, etika berlaku bagi pemimpin maupun pengikutnya. Seorang pemimpin harus melaksanakan kode etik yang berlaku bagi pemimpin sehingga pola kepemimpinannya sesuai dengan aturan yang berlaku. Dalai Lama and Muyzenberg focus on two elements for the leader: on taking the rightview and doing the right thing. Whitin 'taking the right view', they discuss the important elements like thinking the right way (the intention of the action has to be right), being able to think the right way (mindfulness), developing wisdom (study, discussion, listening to others) while accepting reality and staying positive. 'Doing the right thing' is mostly about ethical (standard of), moral behavior. They talk about six perfections: generousity, ethical, patience, enthusiasm, concentration, and wisdom.14

Ajaran Buddha, dalam Teks Jataka memberikan petunujuk berkaitan dengan perilaku seorang pemimpin. Pemimpin yang ideal menurut Teks Jataka harus memiliki sepuluh sifat-sifat luhur seorang pemimpin yang dikenal dengan Dasa Raja Dhamma. Dalam kitab Jataka, Sang buddha

12 http://id.wikipedia.org/wiki/Etika_dalam_agama (diakses pada tanggal 7 Juli 2014, pukul 10:31).

${ }_{13}$ Robert W. Kolb. 2007. Encyclopdia of Business Ethics and Society. London: Sage Publications, hal. 202.

${ }^{14}$ Chris De Boer. 2013. Buddhist Value, Sustainability, and Leadership. Veridian E-Journal, SU Vol. 6, No. 1. hal. 3 . 
memberikan sepuluh persyaratan seorang pemimpin yang baik (Dasa Raja Dharma) yaitu: a. Dana (bermurah hati), seorang pemimpin tidak boleh terlalu terikat dengan kekayaannya, dia memberikan pertolongan baik berupa materi maupun non materi bahkan bersedia mengorbankan hartanya demi kepentingan anggotanya; b. Sila (bermoral), pemimpin harus memiliki sikap yang baik dengan pikiran, ucapan, perbuatan dan hidup berperilaku sesuai dengan aturan moralitas; c. Paricagga (berkorban), seorang pemimpin harus rela mengorbankan kesenangan atau kepentingan pribadi demi kepentingan orang banyak; d. Ajjava (tulus hati dan bersih), memliki kejujuran, ketulusan sikap maupun pikiran dan kebersihan tujuan serta citacita dalam kepemimpinannya; e. Maddava (ramah tamah dan sopan santun), memiliki sikap ramah tamah, simpatik dan menjaga sopan santun melalui pikiran, ucapan dan perbuatan; f. Tapa (sederhana), membiasakan diri dalam hidup kesederhanaan dan tidak berlebih-lebihan dalam kebutuhan hidup; g. Akkodha (tidak berniat jahat, bermusuhan dan membenci), memiliki sifat pemaaf dan bersahabat, menjauhi niat jahat, permusuhan dan kebencian; $h$. Avihimsa (tanpa kekerasan), tidak menyakiti hati orang lain, memelihara sikap kekeluargaan, senang pada perdamaian, menjauhi segala sikap kekerasan dan penghancuran hidup; i. Khanti (sabar dan rendah hati), memiliki kesabaran pada saat mengalami halangan dan kesulitan. Memiliki kerendahan hati pada saat menghadapi hinaan dan celaan, sehingga menimbulkan pengertian dan kebijaksanaan pada saat menentukan keputusan; dan j. Avirodhana (tidak menimbulkan atau mencari pertentangan), tidak menentang dan menghalangi kehendak mereka yang dipimpinnya untuk memperoleh kemajuan sesuai dengan tujuan dan citacita kepemimpinannya. Ia harus hidup bersatu dengan anggota sesuai dengan tuntutan hati nurani. ${ }^{15}$

A good leader should practice all these 10 principles. However, the question remains to what the practice is just 'outside' performance or if these principles are internalized, which means are part of individuality, the personal characteristics of

15 http://becsurabaya.org/artikel-buddhis/152-10-Kompetensi-kepemimpinan-dasa-raja-dhamma.html (diakses pada 4 Juli 2014, pukul 12.45). 
the leader. In that case we could speak of an authentic Buddhist Leader. ${ }^{16}$ Dengan demikian, nilai-nilai yang terdapat dalam Dasa Raja Dhamma harus menjadi karakter dan fondasi dalam bertingkah laku dalam menjalankan pola kepemimpinannya.

\section{Kepemimpinan Modern}

Kepemimpinan merupakan suatu seni (art) dan ilmu (science) untuk mempengaruhi dan menggerakkan orang lain atau orang-orang yang dipimpin sehingga dari orang-orang yang dipimpin timbul suatu kemauan, respek, kepatuhan, dan kepercayaan terhadap pemimpin untuk melaksanakan yang dikehendaki pemimpin, atau tugas-tugas dan tujuan organisasi secara efektif dan efisien. Banyak ahli yang sepakat bahwa kepemimpinan adalah sesuatu yang berkaitan dengan kemampuan mempengaruhi atau menggerakkan orang lain untuk dapat bekerja secara efektif dan efisien dalam mencapai tujuan organisasi. Pemahaman ini mengandung pengertian bahwa seorang pemimpin dituntut untuk memahami perilaku-perilaku orang lain yang menjadi wewenangnya, dan menggerakkan sesuai dengan visi dan misi organisasi. ${ }^{17}$

Sampai saat ini, telah berkembang banyak teori berkaitan dengan kepemimpinan. Meskipun demikian, Guth dan Taguiri menyatakan bahwa kepemimpinan tidak terlepas dari nilai-nilai yang dimiliki oleh pemimpin, antara lain: a. Teoritik, yaitu nilai-nilai yang berhubungan dengan usaha mencari kebenaran dan mencari pembenaran secara rasional; b. Ekonomis, yaitu tertarik pada aspek-aspek kehidupan yang penuh keindahan, menikmati setiap peristiwa untuk kepentingan sendiri; c. Sosial, menaruh belas kasihan pada orang lain, simpati tidak mementingkan diri sendiri; $d$. Politis, berorientasi pada kekuasaan dan melihat kompetisi sebagai faktor yang sangat vital dalam kehidupannya; dan e. Religius, selalu menghubungkan setiap aktivitas dengan kekuasaan Sang Pencipta. Nilai-

\footnotetext{
${ }^{16}$ Chris De Boer. Op. cit. hal. 4.

17 Wahjosumidjo. 2000. Dasar-Dasar Kepemimpinan dan Komitmen Kepemimpinan Abad XXI. Jakarta: Lembaga Administrasi Negara, hal. 4-5.
} 
nilai di atas dapat ditambah lagi dengan beberapa nilai seperti sikap bijaksana dan kesetiakawanan yang tinggi. ${ }^{18}$

\section{Peran Kearifan Lokal dan Etika Buddha dalam Perspektif Kepemimpinan Modern}

Menurut Moendardjito dalam Ayatrohaedi menyatakan bahwa unsur budaya daerah potensial sebagai local genius karena telah teruji kemampuannya bertahan sampai sekarang, dan memiliki ciri-ciri sebagai berikut: a. mampu bertahan terhadap budaya luar; b. memiliki kemampuan mengakomodasi unsur-unsur budaya luar; c. mempunyai kemampuan untuk mengintegrasikan unsur budaya luar ke dalam budaya asli; $\mathrm{d}$. mempunyai kemampuan mengendalikan; dan e. mampu memberi arah pada perkembangan budaya. ${ }^{19}$ Dari ciri-ciri tersebut, nilai kearifan lokal berkontribusi sebagai penyaring (filter) untuk memilih nilai-nilai yang sesuai dengan nilai keperibadian bangsa Indonesia dan menolak nilai yang tidak sesuai. Bagaimana pun juga, pola kepemimpinan yang berkembang saat ini harus disesuaikan dengan nilai kepemimpianan bangsa Indonseia, sehingga proses kepemimpinan dapat berjalan dengan baik.

Sedangkan agama sebagai panduan etika moral dapat digunakan pemimpin sebagai pedoman dalam bertingkah laku. Nilai-nilai yang terkandung dalam ajaran agama harus menjadi karakter dan fondasi yang kuat dalam berperilaku, sehingga dapat menjadi panutan bagi bawahan atau rakyatnya.

Pemimpin yang dapat menggunakan kearifan lokal sebagai penyaring nilai kepemimpinan yang sesuai dan menggunakan nilai etika moral yang terkandung dalam ajaran agama, maka pemimpin tersebut akan berperilaku sesuai dengan yang diharapkan oleh bawahan atau rakyatnya.

18 Irham Hakim. 2013. Perilaku Organisasi: Teori, Aplikasi, dan Kasus. Bandung: Penerbit Alfabeta, hal. 78-79. 


\section{SIMPULAN}

Pola kepemimpinan yang yang berlaku dalam suatu kelompok atau negara tidak selalu sama karena pola ini harus menyesuaikan dengan nilai-nilai kearifan yang berlaku dalam kelompok atau negara tersebut. Selain itu, peran etika moral yang terkandung dalam ajaran agama akan memberikan karakter atau fondasi yang kuat bagi pelaksana kepemimpinan. Agama akan memberikan arah dalam bertindak secara internal dan nilai-nilai kearifan lokal sebagai filter/penyaring nilai-nilai kepemimpinan yang sesuai dengan keperibadian bangsa atau masyarakat.

\section{DAFTAR PUSTAKA}

Adi Sujatno. 2013. Konsep Ideal Kepemimpinan Nusantara Pada Pemilu 2014. Majalah TANNAS Edisi 95, hal. 29-44.

Ajib Rosidi. 2011. Kearifan Lokal Dalam Perspektif Budaya Sunda. Bandung: Kiblat Buku Utama.

Arif Wachjunadi dkk. 2013. Model of Leader Character. Denpasar: Museum Samparaja Bima.

Chris De Boer. 2013. Buddhist Value, Sustainability, and Leadership. Veridian EJuornal, SU Vol. 6, No. 1, hal. 1-9.

http://becsurabaya.org/artikel/artikel-buddhis/152-10-kompetensi-

kepemimpinan-dasa-raja-dhamma.html (diakses pada 4 Juli 2014, pukul 12.45).

http://id.wikipedia.org/wiki/Etika_dalam_agama (diakses pada tanggal 7 Juli 2014, pukul 10:31).

I Gede Wirata. 2011. Kepemimpinan Universal pada Era Globalisasi dalam Konsep Hindu. Jurnal Ganes Swara, Vol. 5, No. 1, hal. 92-99.

Irham Fahmi. 2013. Perilaku Organisasi: Teori, Aplikasi, dan Kasus. Bandung: Alfabeta.

K. N. Jayatilleke. 2008. Ethics in Buddhist Perspective. Sri Lanka: Buddhist Publication Society (BPS Online Edition). 
Nanik Herawati. 2012. Kearifan Lokal Bagian Budaya Jawa. Jurnal Magistra No. 79, Tahun XXIV, hal. 64-70.

Robert W. Kolb. Enceyelopedia of Business Ethics and Society. London: Sage Publications.

Sartini. 2004. Menggali Kearifan Lokal Nusantara Sebuah Kajian Filsafati. Jurnal Filsafat Jilid 37 No. 2. Hal. 111-120.

Siti Supeni dan Kundharu Saddhono. 2013. Cognitive Behavior Has Replaced The Javanese Traditional Values In Global Era. Asian Journal of Management Sciences and Education. Vol. 2, No. 2, hal. 156-162.

Sulistiyo Seti Utami. 2013. Gaya Kepemimpinan Gubernur DKI Jakarta Berdasarkan Prinsip Tata Kelola Kepemerintahan yang Baik (GCG). Jurnal Liquidity ol. 2 No. 2, hal. 160-169.

Wagiran. 2012. Pengembangan Karakter Berbasis Kearifan Lokal Hamemayu Hayuning Bawana. Jurnal Pendidikan Karakter, Tahun II, Nomer 3, hal. 329-339.

Wahjosumidjo. 2000. Dasar-dasar Kepmimpinan dan Komitmen Kepemimpinan Abad XXI. Jakarta: Lembaga Administrasi Negara. 